\title{
A Comparative Study of the Development of Technology-Intensive Industries: Korean and Romanian Automobile Industries
}

\author{
Jae Min Kang ${ }^{1} \&$ Jai S. Mah ${ }^{1}$ \\ ${ }^{1}$ Ewha Womans University, Seoul, South Korea \\ Correspondence: Jai S. Mah, Division of International Studies, Ewha Womans University, Seodaemun-gu, Seoul \\ 03760, South Korea. Tel: 82-10-8300-8836. E-mail: jsmah@ewha.ac.kr
}

Received: April 8, 2020

doi:10.5430/rwe.v11n3p1
Accepted: May 22, 2020

Online Published: June 15, 2020

URL: https://doi.org/10.5430/rwe.v11n3p1

\begin{abstract}
The automobile industry is a technology-intensive industry that has the potential to create successes in many other related industries. This paper analyzes the approaches taken during the developmental processes of the automobile industries in Romania and Korea. This paper identifies the causes of their rapid growth and compares the experiences of the two nations particularly with respect to the approaches they took during the developmental stages of their automobile industries. Automobile industries in these two countries, Dacia and Hyundai in particular, contributed to economic growth in terms of employment, income generation and development of advanced technologies via the linkage effect. After comparing the merger and acquisition approach in Romania with the technology licensing approach in Korea in light of the government policies which pursued industrialization since the 1960s, it provides policy implications for developing countries which try to develop technology-intensive industries such as the automobile industry.
\end{abstract}

Keywords: automobile industry, technology, Korea, Romania

\section{Introduction}

Both Romania and South Korea, Korea hereafter, pursued industrialization, which enabled them to record rapid economic growth and structural transformation. Both nations tried to promote value-added technology-intensive industries such as the automobile industry. To explain the economic development of these two economies, it is worth focusing on the development of the automobile industry due to its large contributions to generating many job opportunities, creating advanced technologies, and contributing to the development of the other related industries through the use of their components (Egresi, 2007: 748; Lee and Mah, 2017: 229).

Contrary to the view of economic liberalism holding the belief that government intervention hinders resource allocational efficiency, Korea and Romania were able to develop their own brand models in the early stage of the development of the automobile industry with the support of their respective governments. Both nations showed that the government played a significant role in promoting this industry, which in turn contributed to the economic development of the national economy as a whole. Typically, in the process of promoting technology-intensive industries, developing countries have followed one of two different approaches in order to acquire the production technologies of developed countries, namely, foreign direct investment (FDI) inflows or technology licensing. Romania adopted the former approach, while Korea took on the latter during the early developmental stage of its automobile industry. Korea successfully developed its own advanced technology of production through independently conducted, intensive research and development (R\&D) efforts as well.

Dacia, the leading automobile manufacturer in Romania, started out as a joint venture with Renault in the 1960s (Egresi, 2007: 752). This endeavor took place when Nicolae Ceausescu took power in 1965 and when he had aims of demonstrating Romania's economic capabilities as a socialist republic (Groupe Renault, 2013a). When his ideas became a reality through the acquisition of a foreign partner, Dacia flourished not only domestically, but also globally. Domestically, it accounted for 40 percent of market share and its production level was raised from 70,000 units in 2003 to 200,000 units in 2006, as Renault invested more to modernize Dacia's factory. Internationally, Renault helped Dacia open assembly plants in various countries, which raised the quantity of automobile production through the use of the complete knock down (CKD) method in international assembly plants (Egresi, 2007: 752). 
On the other hand, the Korean giant, Hyundai, was able to prosper in the midst of the Korean government's pursuit of the heavy and chemical industries promotion policy since 1974. The Korean government tried to protect and subsidize the automobile industry during the mid-to late 1970s (Mah, 2007; Lee and Mah, 2017). As a large conglomerate called chaebol, Hyundai Group, whose development started in the construction sector, entered the automobile industry. The government's financial support, that had underlying intentions to encourage domestic companies to develop their own models and restrict foreign imports through high tariff barriers, allowed Hyundai Motors Company, Hyundai hereafter, to benefit from borrowing at low interest rates, enabling the company to produce its first own brand model called Pony in 1975. The model took a low-cost approach since 90 percent of its parts were sourced locally, which allowed it to face great success. Its market share in Korea's automobile market accelerated to 58 percent in 1977. In addition to the initial strategy of mass production, economies of scale and the consequent low cost of production enabled Hyundai to penetrate into the global market, with Canada being its first target. Thus, such efforts made it possible for the conglomerate to record rapid growth during the 1970s and 1980s both domestically and internationally (Lansbury et al., 2007: 49-52).

By analyzing the data and reviewing the literature, this paper tries to identify the root causes of their rapid growth and compares the experiences of the two nations particularly with respect to the approaches they took during the developmental stages of their automobile industries in light of the cases of Dacia and Hyundai. Both Romania and Korea tried to promote value-added technology-intensive industries such as the automobile industry. Automobile industries in these two countries, Dacia and Hyundai in particular, contributed to economic growth in terms of employment, income generation and development of advanced technologies via the linkage effect. Research on this topic is expected to provide policy implications to developing countries wishing to promote their technology-intensive industries. To do so, Sections 2 and 3 explain how the automobile industries have been developed in Romania and Korea, respectively. Section 4 analyzes the approaches to technology acquisition and development of the automobile industry regarding the two nations. Section 5 provides the policy implications for developing countries with respect to the experiences of Romania and Korea and their automobile industries. Conclusions are shown in Section 6.

\section{The Development of Dacia in Romania's Automobile Industry}

Until the late-1990s, Romania's economic performance lagged behind most European countries. Its GDP per capita remained between US\$1,600 and US\$1,700 during 1980 - 1999. Despite overall positive economic growth during the 1980s, Romania experienced an overall negative economic growth rate during the 1990s, which was experienced by most of the former socialist countries following the break-up of the Soviet Union in 1991. However, it began to recover starting the year 2000 and recorded an annual average real GDP growth rate of 3.9 percent throughout 2000 - 2017. Reflecting fairly rapid economic growth excluding the few years during the global financial crisis in the late 2000s, Romania's GDP per capita rose from a mere US\$1,692 in 2000 to over US\$10,000 in 2017 (source: UNCTAD, 2019). One of the largest contributions to the rapid economic growth of the Romanian economy since 2000 was made by the automobile industry (Ahrens and Zweynert, 2012: 291).

Large-scale automobile producers were not present in Romania until the middle of the $20^{\text {th }}$ Century. Three important automobile producers were on the rise: Roman, Rocar, and Aro. In the second half of the $20^{\text {th }}$ Century, two state-owned automobile producers quickly came on the rise: Dacia and Craiova. Under the communist regime, there was a rise of state-owned enterprises that were heavily supported by the government. Such enterprises would have a certain number of their products, guaranteed every year through central planning, to be exported to other Council for Mutual Economic Assistance (CMEA) countries (Egresi, 2007: 751-752).

Dacia was established in 1966. With the aim of production in the low-cost sector, it made the decision to produce its first model, the Renault 8, under license. Dacia's capacity to produce automobiles was insufficient, given the status of Romania's automobile industry during the late 1900s (Martin, 2017). Due to such conditions, the production of the Dacia 1100 began in 1968 with its initial manufacturing process taking place in France and all of its components imported. Until the end of 1971, 37,546 units of the model were produced. The models produced since the 1970 s, i.e. the Dacia 1300 and 1310, were considered "the stars of Dacia." The Dacia 1300 was produced from 1969 to 2004 , and helped record two million automobiles being produced (Groupe Renault, 2013a). It was designed as a standard car available for the commons and aimed for mass production, while it was not satisfactory in technology and design (Turi et al., 2015: 481).

The first Dacia model fully designed by Romanian engineers, i.e. Dacia Nova, was launched in 1996 (Groupe Renault, 2013a). Although Dacia did not reveal specific numbers related to production and sales during this time period, it can be assumed that production during the 1990s took a downturn. The Dacia Nova was about 33 percent more expensive in comparison to its classic model, which caused the company to deviate from its low-cost image, 
and Dacia during this time also faced structural issues that resulted in its slow progress (Turi et al., 2015: 481). In addition, Dacia faced greater competition due to increased imports of foreign cars, whereas previously, Dacia's vehicles dominated Romania. The primary factors that led to the struggles of Dacia included outdated factories in addition to equipment and designs that severely fell short of its foreign competitors (Martin, 2017). However, once the communist regime fell and a large number of previously communist countries shifted towards capitalist economies, trade liberalization progressed and Romania faced increased competition against foreign automobiles. Despite numerous efforts held by the government to sustain its domestic automobile companies through the provision of subsidies, all of the aforementioned manufacturers failed to resist the post-1990 trauma (Egresi, 2007: 751-752).

In the late 1990s, Dacia was seeking a partner to revive its brand and Renault was prepared to step up the pace of its internationalization. Renault considered Dacia to have two virtues that made it attractive. First, it was free of conflicts related to its brand image and second, it had a well-established production facility at Pitesti with highly-skilled engineers and technicians (Groupe Renault, 2013b). Overall, Renault envisioned Volkswagen's success with Skoda (Worrall et al., 2011: 11). In July 1999, both sides signed the final agreement on merger and acquisition (M\&A). Renault acquired a 51 percent stake in Dacia for $€ 47$ million and also promised to invest an additional €208 million in 2004 once profitability was to be achieved. The introduction of a new car model introduced by Renault to Dacia would target sales of discount cars mainly in developing countries (Worrall et al., 2011: 11; Groupe Renault, 2013b).

The Romanian government aimed to revitalize the automotive industry by attracting FDI through investment incentives mainly provided to Dacia. The government provided incentive schemes such as exempting customs duties and offering tax holidays on profits being conditional upon using the Romanian local content of 50 percent and exporting a minimum of 50 percent of local production. Investment incentives were removed in 2002, since they were inconsistent with WTO regulations (World Trade Organization (WTO), 2005: 75). Consequently however, high tariff rates contributed to the development of the automobile industry in Romania. For instance, in the early 2000s, most-favored-nation (MFN) tariff rates on automobile imports reached 21.5 percent. Romania's automobile industry grew rapidly since 2000 , with sales of 180,927 units in 2004 , up from 84,170 units in 2000 . Vehicles manufactured in Romania accounted for 67.5 percent of total sales in 2004. This allowed Dacia to become the leading car manufacturer in Romania, accounting for 44.2 percent of total domestic sales of automobiles that same year (WTO, 2005: 74).

For Dacia, conditions drastically changed once it was acquired by Renault. For instance, the Dacia Supernova was introduced in 2000 with an upgraded engine and interior design (Turi et al., 2015: 482). In less than two years, Dacia, with the help of Renault, produced about 80,000 cars (Groupe Renault, 2013a). Furthermore, Renault launched the Logan Project to develop a model considered to be a discount price car (Groupe Renault, 2013b). Through an increased share of 93 percent in 2001 due to stock acquisitions and establishment of dealerships, Renault developed a new model, X90, to be sold for $€ 5,000$ (Worrall et al., 2011: 11). Dacia and Craiova became the only two car makers remaining in Romania in the mid-2000s. Out of the two automobile producers that survived the collapse of communism, Dacia came to be the leading manufacturer (Egresi, 2007: 751-752).

Renault's share in Dacia increased to 99.3 percent in 2003. Then in 2004, Logan was launched, which made way for an immediate sales success. The introduction of a new automobile model by Renault to Dacia was an endeavor to target sales mainly in developing countries (Groupe Renault, 2013b). The success of the budding model could largely be attributed to its cheap price in addition to its good quality (Turi et al., 2015: 482). This made the Logan project become the keystone of the brand, which then quickly led to the expansion of the Dacia range and the exposure to new markets on a global scale (Groupe Renault, 2013a). Renault expected the production capacity of Dacia to rise to 200,000 units and 150,000 CKD kits for other production sites by 2005 (Groupe Renault, 2013b). The automobile industry employed 3.5 percent of total workers in the manufacturing sector in Romania in 2004 (WTO, 2005: 74).

A decade after the Logan was launched, the Dacia plant, as a modern factory, was able to produce a wider range of models, employ twice the number of workers, quadruple wages, and export 95 percent of products. Production level reached a peak after Renault made modernization efforts, recording an average of 92 percent of maximum capacity from 2009 to 2015. During the 2000s, production levels have grown more than 3.5 times and sales have increased by approximately 5.5 times (Turi et al., 2015: 482).

As of the mid-2010s, two major companies started to dominate the automobile industry in Romania: Dacia-Renault and Ford (Nedelcu, 2015: 82). Dacia has definitely excelled in the European market due to high demands and 
favorable conditions. Dacia sold more than 5 million cars since 2004 (Groupe Renault, 2018). About 60 percent of Dacia's export destinations were directed to Western Europe. In 2009, Dacia's main European markets included Germany, France, and Italy, with 84,875 units, 66,531 units, and 21,754 units sold, respectively (Turi et al., 2015: 483).

Unlike the small percentage of exports of merely 16 percent that were made in 2004, two-thirds of Dacia's automobiles produced were exported in 2009. Furthermore, approximately 95 percent of Dacia's automobiles were exported in 2015. More specifically, Dacia sold around 15,000 vehicles outside of domestic borders in 2005, but sold 32 times this number ten years later, sharing 10 percent of total national exports (Turi et al., 2015: 483). Other international markets included Maghreb and African countries. Dacia became the dominant automobile producer in Morocco and Algeria, for instance, selling 18,100 and 17,300 units, respectively, in 2009 (Funaru and Funaru, 2011: 32-33).

\section{The Development of Hyundai in Korea's Automobile Industry}

The Korean government since the 1960s expected to install automobile factories specifically for small passenger and commercial vehicles. These efforts allowed the automobile industry to transform from a 'knock-down' (KD) assembly factory to one of self-sufficiency according to the Localization Plan for Imported Auto Parts during 1962-1967. In response, the Saenara Motor Company (SMC) was established, producing small passenger cars through the assembly of 'semi-knock-down' (SKD) parts of a Nissan model. Meanwhile, this plan failed due to the lack of foreign capital for the maintenance of the industry and the continuation of importing KD components. Another reason why automobile production failed to develop any further was because many foreign producers viewed Korea as a market for export instead of local production, which made them reluctant to transplant high technology production facilities to the peninsula. This caused SMC to produce only a few hundred cars each year in 1964 and in 1965 and show localization of auto parts to record a very low level of approximately 20 to 27 percent during the early 1960s. Such numbers indicate the failed venture of the state's plan for the localization of automobile components during the 1960s (Lansbury et al., 2007: 49-50).

An additional attempt made by the government was to form business partnership arrangements with manufacturers in developed countries, which consisted of adopting foreign licenses and technical agreements with Ford in 1967 (Amsden, 1992: 175). This partnership resulted in the production of Ford models making use of imported CKD parts. Furthermore, SMC was replaced by Shinjin Motors in 1965, which began to produce Toyota car models with the aid of Toyota Motor Company. Such events led to the increase of production capacity for the automobile industry in Korea, which started off with 4,000 passenger cars in 1965, followed by 15,000 in 1968 and 28,000 in 1971 (Lansbury et al., 2007: 50).

The government's active industrial policy contributed to the rapid economic growth particularly during the 1970s. It pursued the heavy and chemical industries drive since 1973 and protected several selected strategic industries including those of steel, shipbuilding, machinery, electronics, non-steel metal, chemical and petroleum. The heavy and chemical industries drive consisted of policy loans at preferential lending interest rates, selective protection by high tariff rates, entry regulations, and corporate tax deductions (Mah, 2007: 79).

As a part of the heavy and chemical industries drive, the Korean government established the Automobile Industry Long-term Promotion Plan in 1974. It articulated the need for a mass production of domestically produced small-sized cars. Starting from 1975, the government set the ambitious goal of developing a domestically produced, economical car with a local content ratio of over 95 percent. The Plan set the target of producing 50,000 cars each year and lowering the average cost of production to lower than US\$2,000 through economies of scale (Oh, 1996). In addition, the government set very high import tariff rates to protect the burgeoning automobile industry. More specifically, it raised the import tariff rate imposed on automobile imports from 150 percent to 250 percent in 1974 (Lee and Mah, 2017: 234).

Having considered the importance of components when it comes to automobile production, the Korean government required car manufacturers to establish factories producing important automotive parts. Hyundai Group, which established Hyundai Motor Company (HMC) in 1967, expressed its eagerness to develop the company's own car model to achieve further development and to compete with other multinational car manufacturers in the international market. In 1975, Hyundai became the first domestic automobile company in Korea to produce its own car model called Pony (Graham, 2003: 37; Lee and Mah, 2017: 231).

Hyundai acquired production technologies from various sources such as Japan, Britain, and Italy, in which eighteen technology transfers enabled the company to create its first own car model (Amsden, 1992: 175). Thus, in the case of 
Hyundai, the technologies needed in producing automobiles were acquired through technology licensing. An important point to recognize is that although Korea made tremendous efforts to acquire various forms of technologies and capital from foreign sources, such attempts were taken to build upon self-reliance in the long-run. Thus, despite the fact that the Pony was composed of various imported components, it was deemed Hyundai's first truly Korean car due to its domestic design (Graham, 2003: 37). In the late-1970s, Hyundai conducted further procedures that involved a greater number of technology licenses from Japan, Britain, and the United States (Amsden, 1992: 175). The automobile industry belonging to the machinery sector came to play as one of the most important industries in the economic development of the Korean economy (Lansbury et al., 2007: 49).

Since the 1980s, three automobile producers, i.e. Daewoo, Hyundai, and Kia, played key roles in developing the Korean automobile industry (Lansbury et al., 2007: 51). However, it can be asserted that Hyundai could continue to take on a leading position because of its outstanding market share and top ranking in comparison to its domestic counterparts. Thus, Hyundai had the greatest influence in shaping Korea's automobile industry over the years.

The government provided many kinds of tax and financial incentives to the selected industries during the 1970s, whereas Korea's direction of industrial policy began to change in the 1980s. In other words, the industrial policy of Korea changed from being sector-oriented and promoting exports, to being function-oriented and focusing on R\&D promotion. Government intervention in the market began to decrease in the early 1980s (Mah, 2007). From then on, private companies including Hyundai began to increase their R\&D expenditures drastically (Lee and Mah, 2017: 232).

Although only about 37,000 cars were produced in 1975, production of automobiles increased to over 370,000 in 1985 and then to 2,530,000 in 1995. Consequently, Korea became the fifth largest producer of automobiles in 1995. With the rapid development of the automobile industry, the Korean government decided to gradually reduce import tariff rates imposed on automobile imports. The most-favored-nation (m.f.n.) tariff rate applied to imports of passenger cars decreased to 10 percent in 1993 and then to 8 percent in 1998 (Lee and Mah, 2017: 232, 235). In 2017, Korea was ranked as the sixth largest producer of automobiles, producing 4.1 million cars and sharing 4.2 percent of world production of automobiles (Korea Automobiles Manufacturers Association, 2018).

Hyundai and Kia are Korea's leading automobile manufacturing companies, although the latter was acquired by the former in late 1990s. Out of the two, however, it can be said that Korea's largest car maker is Hyundai in terms of both production and sales. Hyundai has been excelling in the automobile industry domestically, but has also been considered one of the leading automobile manufacturers internationally. Table 1 provides the changing brand values of Hyundai. It showed a brand value of US\$3.5 billion and a world ranking of 84th in 2005, while its brand value skyrocketed to US\$10.4 billion with a world ranking of 40th in 2014. Together with Kia, Hyundai was able to sell 4.0 million units, which includes automobiles produced both within Korea and in the factories located outside of Korea, in 2007, ranking $6^{\text {th }}$ in the world, and 8.1 million units in 2015 , becoming one of the world's top five car manufacturers (Hyun and Kim, 2016: 114).

Table 1. Brand Value and Brand Ranking of Hyundai in the World

\begin{tabular}{lll}
\hline Year & $\begin{array}{l}\text { brand value } \\
\text { (US\$ billion) }\end{array}$ & brand ranking \\
\hline 2005 & 3.48 & 64 \\
2007 & 4.45 & 72 \\
2009 & 4.60 & 69 \\
2011 & 6.00 & 61 \\
2013 & 9.00 & 43 \\
2014 & 10.40 & 40 \\
\hline
\end{tabular}

$\begin{array}{llllll}\text { Source: } & \text { Interbrand, } & \text { Retrieved } & \text { February } & 8, & \text { 2019, }\end{array}$ https://www.interbrand.com/best-brands/best-global-brands/2014/ranking/hyundai.

\section{Analysis of the Approaches to Development of the Automobile Industry}

Romania and Korea took two very different approaches when it comes to industrial expansion. Although the two countries took very different strategies when it comes to developing their automobile industries and national 
economies, they also share similarities. Thus, in order to recognize their differences as well as their similarities, their historical and present economic status must be observed through a more cohesive lens to analyze how successful each approach was. Such an analysis will be made by examining the economic impact the automobile industry had on their respective nations.

\subsection{Romania}

Romania was a part of the sphere of influence dominated by the Soviet Union since the end of the Second World War, as was the case for most other Eastern European countries at the time. Therefore, Romania was ruled by communist forces that maintained dictatorship. This was when the socialist centralized planned economy was established. Through nationalization, capitalist means of production were confiscated and state-owned property flourished (Axenciuc and Georgescu, 2017: 119).

In the 1940s, Romania focused on utilizing its own resources. Economic growth during this period was slow due to the severe damages from the war. With Nicolae Ceausescu as the new communist leader and with the aim of boosting the level of economic growth in the 1960s, Romania underwent a process of becoming more open to the rest of the world. Romania collaborated with international economic organizations to participate in the global market, became a member of the International Monetary Fund (IMF), and received loans from Western financial institutions to build on its infrastructure and technology. This explains Dacia's joint venture with Renault and why Romania's real GDP growth rate was the highest amongst the communist states during this time. Hence, during 1950 - 1979, Romania experienced sustained economic development through the inflow of foreign capital, which led to significant structural transformations within the nation, including its automobile industry (Axenciuc and Georgescu, 2017: 120).

Oftentimes, the economic transformation of former socialist countries have been acknowledged to historical or political factors, with industrial influences being understated. Although historical events and political backgrounds cannot be overlooked, they must be considered with a more collective perspective, being inclusive of economic factors or more specifically, through the analysis of specific industrial sectors. Because certain industries, particularly the automobile industry, played such a significant role in contributing to Romania's economic status, the automobile industry deserves an in-depth explanation when it comes to describing its national economy.

The share of industry value added in GDP at the initial stage of transition was 49.9 percent in 1990, with the automobile industry forming a great counterpart (Myant and Drahokoupil, 2010: 42). Together with industrialization, Romania showed fairly high dependence on exports. For instance, as of 2016, it was the 40th largest economy in export values, which amounted to US $\$ 64.8$ billion. The leading export products of Romania included vehicle parts, insulated wire, cars, wheat, and rubber tires, in which vehicle parts and cars made up of US $\$ 5.3$ billion and US $\$ 3.5$ billion, respectively, in 2016 (Observatory of Economic Complexity, 2016). In order words, Romania's exports of cars and vehicle parts reached US $\$ 8.9$ billion, accounting for 14 percent of its total exports in 2016. Dacia maintains its position as the most profitable company in Romania to this day, being responsible for 2.8 percent of Romania's GDP and 7.3 percent of the nation's exports in 2013 (Bernovici, 2015). Table 2 shows the main destination of Romania's exports of Dacia. France takes the leading position, followed by other Western European countries and a few countries in North Africa. Thus, it is undoubtedly true that Dacia plays a significant role in Romania's economy as a whole as well as its exports.

Table 2. Top 10 Export destinations of Romania's Dacia

\begin{tabular}{ll}
\hline Country & Units Exported \\
\hline France & 119,356 \\
Germany & 64,918 \\
Italy & 63,374 \\
Spain & 56,301 \\
Turkey & 48,370 \\
Morocco & 46,848 \\
Algeria & 30,776 \\
UK & 25,211 \\
Poland & 23,944 \\
Belgium & 20,000 \\
\hline
\end{tabular}

Source: Groupe Renault. (2018). Facts and Figures: March 2018. Retrieved August 25, 2018, from https://group.renault.com/wp-content/uploads/2018/03/facts-figures-march-2018-edition.pdf. 
Dacia accounted for about 40 percent of market share domestically. Renault made an investment of US\$800 million to modernize Dacia's factory, helping its production increase from 70,000 units in 2003 to 200,000 units in 2006, also increasing exports made internationally to 89,000 units. In addition, Renault helped open assembly plants internationally such as in Colombia, Russia, and Morocco. Thus, the good performance of Dacia in Romania since the 2000s could be mainly attributed to the Romanian government's approach to attract FDI to its automobile sector (Egresi, 2007: 752).

\subsection{Korea}

Korea, in comparison to Romania, has gone through a different experience in that, among others, the former has been governed by a capitalist system. Despite this difference, however, Korea and Romania share two common attributes. One is that businesses in both nations were heavily influenced by their respective governments and another is that they both have been heavily dependent on exports. Since around 1964, the Korean government switched the direction of economic development strategy from import substitution to export promotion. The Korean government promoted heavy and chemical industries, which can be characterized by economies of scale. It provided policy loans at preferential interest rates and various tax incentives to chaebols, which became the main beneficiaries of the heavy and chemical industries promotion policy pursued by the Korean government during the 1970s (Kim, 1991: 38; Mah, 2007).

Hyundai belonging to Hyundai Group, one of the largest chaebols in Korea, continued to grow to even become one of the world's largest multinational corporations. When looking at the current statistical evidence, cars and vehicle parts constitute a significant proportion of Korea's exports like the case for Romania. Korea is ranked the 5th largest exporter in the world, in which its exports amounted to US\$515 billion in 2016. The leading export products of Korea include integrated circuits, cars, refined petroleum, passenger and cargo ships, and vehicle parts. Exports of vehicle parts and cars reached US\$20.1 billion and US\$38.4 billion, respectively, in 2016 (The Observatory of Economic Complexity, 2016). Thus, the share of cars and vehicle parts in Korea's total export values reached more than 11 percent in 2016. Given that Hyundai is Korea's leading automobile manufacturer, it can be said to have contributed significantly to the export-led economic growth of Korea.

\subsection{Romania and Korea Compared}

Hyundai's performance shows that technology licensing played a critical role in its initial development and that the acquisition of Kia helped further bring the conglomerate to the dominant position it has maintained to this day. Therefore, it can be questioned whether Dacia will be able to gain more success internationally and whether it will be able to compete against the other multinational corporations that dominate the global market. It may also be questioned whether Dacia has reached the same amount of success as Hyundai on a domestic and international scale. As mentioned previously, the growth of Dacia, unlike that of Hyundai, has relied more on FDI. Based on its recent performance, Dacia's success seems to have been more valid domestically and within the borders of Europe, whereas Hyundai's success has been applicable both domestically and internationally.

Apart from the fact that Dacia has been producing a greater number of cars over the years and has experienced a significant amount of growth, its numbers are still nowhere near that of Hyundai's. This can be explained by the restricted size of the domestic market that appears to constrain the Romanian automobile industry. Table 3 shows total sales of new vehicles in Romania and Korea. It shows that in the late 2000s, sales of new vehicles decreased substantially in Romania. That is, they decreased from 248,462 units in 2005 to 104,090 units in 2010. Although they increased in the 2010s, the number of sales of new vehicles was as small as 142,020 in 2016, which is only about 0.15 percent of sales of new vehicles in the world economy as a whole. Meanwhile, the number of domestic sales of new vehicles continues to be over 1 million units in case of Korea. It increased from 1,145,230 units in 2005 to $1,823,041$ units in 2016, sharing about 2 percent of sales in the world economy as a whole.

Table 3. Domestic sales of new vehicles

\begin{tabular}{llll}
\hline Year & Romania & Korea & World \\
\hline 2005 & 248,462 & $1,145,230$ & $65,923,794$ \\
2010 & 104,090 & $1,511,373$ & $74,971,523$ \\
2015 & 120,591 & $1,833,786$ & $89,684,608$ \\
2016 & 142,020 & $1,823,041$ & $89,684,608$ \\
\hline
\end{tabular}

Source: Romanian Automotive Manufacturers and Importers Association (2019). Retrieved February 3, 2019, from http://www.apia.ro/publications/international-statistics/oica.. 
Even as the leading producer of automobiles in Romania, Dacia was ranked 60th in contrast to Hyundai's high world ranking in the automobile industry, which shows that Dacia still has a long way when it comes to global success (Haigh, 2018). However, within the borders of Romania, Dacia remains the most valuable brand and is one of the few Romanian companies that has a place in global rankings. Despite the fact that Dacia falls short of Hyundai's success, it must still be acknowledged that its international sales has increased rapidly over the years, since 90 percent of its local outputs are exported. In addition, its brand value has increased, recording $€ 4.3$ billion in 2018 (Marica, 2018).

Moreover, although it is commonly believed that communism generally hinders economic growth due to heavy government intervention particularly when it comes to resource allocation mechanisms, it can be argued that a communist regime actually helped Romania's automobile industry flourish. This may be supported by the fact that Romania is no longer a nation with a communist regime and that it has made tremendous efforts towards trade liberalization over the years, which made it inevitable for the nation to encounter a greater amount of competition against foreign car manufacturers. Contradictory to the past in which the communist government helped guarantee certain exports to be made, a movement towards a capitalist system lifted restrictions on foreign imports and no longer guaranteed exports to CMEA countries, which made it increasingly difficult for car manufacturers to thrive during times of transition in the 1990s.

Because Korea utilized technology licensing in order to improve its own productivity, in the long run, the nation was able to undergo a greater amount of growth compared to Romania. Thus, Hyundai still has a high level of production and exports in comparison to Dacia. In addition, Dacia still has a long way when it comes to developing its brand image. Despite the fact that it has obtained numerous consumers within the continent of Europe and is slowly expanding its borders, the brand's reputation is still incomparable to that of Hyundai's. Therefore, based on our analysis, it can be concluded that both Dacia and Hyundai have acquired a great amount of success within their home countries and it can also be concluded that both companies have experienced a significant amount of growth compared to the past. But when directly comparing these two companies, Hyundai has attained a great amount of global success in addition to domestic success, which is the main differentiating point between the two brands.

Regardless of their individual performances, however, it can be argued that both Dacia and Hyundai had striking influences on Romania's and South Korea's economies, respectively, due to the linkage effect exerted by the automobile industry to other related industries. Consequently, the high number of exports in automobiles in turn resulted in high exports of related goods, which further contributed to each country's GDP as a whole. Such economic impacts were made because of the approaches each country took. After Renault acquired Dacia, the brand experienced a significant increase in production levels and after Hyundai engaged in technology licensing, it was able to become more self-reliant, which allowed it to further build upon its brand and manufacturing strategies. Although it can be concluded that Dacia has gained unarguable success within Europe, it can be questioned whether the success of Dacia can be attributed to Romania since, although the company itself has stemmed from Romania, its growth and success was attained mainly due to its acquisition by France's Renault.

\section{Policy Implications for Developing Countries}

Korea's GDP per capita rose from US\$279 in 1970 to US\$30,165 in 2017, while that of Romania rose from US\$619 in 1970 to US\$10,665 in 2017 (source: UNCTAD, 2019). The automobile industry has undoubtedly played a very important role in economic growth for both countries. For instance, exports of automobiles and car components account for more than 10 percent of total exports in both countries.

It is difficult to say whether Romania would have gained greater success if it took an approach that was more similar to that of Korea. This is primarily because Romania had a different political background compared to Korea. According to historical and statistical evidence, it can be concluded that Dacia's growth was heavily dependent on its joint venture with Renault. Although Dacia was able to survive against other domestic companies with the help of the Romanian communist government, substantial growth was attained thanks to Renault's ownership. If Dacia had to continue depending on the government, it could be assumed that the company would have collapsed with the fall of the communist regime. Thus, Dacia's resistance to the chaotic reforms following the fall of the communist regime in addition to its development can be largely attributed to its partnership with Renault. This is because Renault was the primary factor in contributing to the initial success of Dacia by preventing its subsidiary from falling along with communism, which was what happened to most of the automobile manufacturers during the time. Therefore, in short, it is debatable whether Dacia would have been able to exist today without the acquisition of Renault.

Regarding the approach that was taken by each country, it can be concluded that Korea was more successful in comparison to Romania in terms of exports, GDP per capita, and influence from the automobile sector. The automobile industry of Korea has been more successful in terms of reputation as well. Hyundai was not only able to penetrate a 
greater number of markets in the global field, but was also able to develop a brand image that is much more renowned than that of Dacia. Based on the success of Hyundai individually and that of the Korean economy as a whole, it can be assumed why there are numerous developing countries that are currently aiming to imitate the rapid economic growth that Korea showed, whereas the same is not true for Romania.

Following the dramatic rise of the two countries that were continuously dealt with throughout this paper, there have been numerous debates about whether currently underdeveloped or developing countries should emulate their export-driven development model. It can briefly be summarized that both Korea and Romania favored certain industries such as that of automobiles, which in turn allowed the two countries to reduce the number of imports and increase their number of exports to attain a positive balance of payments. This helped increase funds, which could be reinvested to further strengthen businesses or the infrastructure of the country. The attempts made to strengthen the automobile industry and in turn the national economy were largely supported by the government.

In the 1960s, with the decision of the government, Romania became more open to FDI with the goal of increasing the competitiveness of its businesses. This made it possible for Dacia and Renault's joint venture, which eventually led to an acquisition almost four decades later. Renault's role was significant in Dacia's operations because it did not only help launch the Logan Project which led to Dacia's representative brand model, but also created a large impact on Romania's labor force. After Renault acquired Dacia in 1999, Renault invested around $\$ 800$ million to develop Dacia's factory, which did not translate to the increased use of automated machines but rather meant the utilization of cheap Romanian labor (Egresi, 2007: 752).

The impact of Renault's acquisition of Dacia on the Romanian economy might not have been so substantial if the former decided to import components from outside of Romania and assemble those in the Romanian factory. Renault-Dacia instead tried to develop its own model to sell domestically and internationally, which contributed to upgrading the level of technology for the automobile industry and the national economy as a whole. With the acquisition of Dacia, Renault tried to make an economy car appropriate for niche markets in Western Europe as well as in some developing countries where customers cannot afford to buy more relatively expensive Western European brand cars. In this process, Renault did not only help Dacia in terms of increasing its production, but also helped increase the employment rate of Romania as a whole.

For Korea, during the process of recovering from the destruction that resulted from the Korean War, the nation encouraged the use of technology licensing to jump start economic growth. The Korean government started to implement industrial policies that supported technology transfers to firms so that they can go through a learning process which was provided by the importation of technology from Japan, Western European countries and the US (Koo, 2013). This in turn increased the government's R\&D investment, which allowed Korea to start developing its own model car in 1975 . The government protected the automobile industry by setting a high import tariff wall in the early stage of development. Thus, local content ratio increased rapidly during the late 1970s and 1980s.

Realizing the benefits of economies of scale property within the automobile industry, both Romania and Korea tried to enlarge production scales. Both targeted promoting the exports of automobiles produced. Although export shares of their products are very high in both countries, in terms of reputation in the international market, Hyundai might be said to be more successful in the sense that it became one of the largest producers of automobiles since the 2000 s. Another reason supporting the greater success of Korea can be found in the utilization of the economies of scale property and efforts of developing its own models that can compete with car brands that are already popular in the international market.

\section{Conclusion}

Both Romania and Korea tried to develop value-added technology-intensive industries such as the automobile industry. Automobile industries in these two countries contributed to economic growth in terms of employment and income generation as well as development of advanced technologies via the linkage effect. In the case of Romania, the leading automobile manufacturer, Dacia, was established in 1966 as a joint venture with Renault. The first Dacia model fully designed by Romanian engineers was launched in 1996 (Groupe Renault, 2013a); meanwhile, production by Dacia took a downturn during the 1990s, as it faced greater competition due to increased imports of foreign cars, among others. In 1999, Dacia and Renault signed the agreement on M\&A. The introduction of a new model introduced by Renault to Dacia expected to target sales of discount cars mainly in developing countries (Worrall et al., 2011: 11; Groupe Renault, 2013b). The Romanian government tried to revitalize the automotive industry by attracting FDI through investment incentives and high import tariff rates in the early 2000s (WTO, 2005: 74-75). Romania's automobile industry was able to grow rapidly since the year 2000. Exports of automobiles began 
to increase sharply and approximately 95 percent of Dacia's automobiles were exported in 2015 (Turi et al., 2015: 483).

For Korea, on the other hand, the leading car manufacturer, Hyundai, was established in 1967. As the Korean government tried to protect and promote heavy and chemical industries since 1974, Hyundai was able to grow rapidly, producing Korea's first own brand car model in 1975. Hyundai mainly relied on technology licensing in the early stage of production (Lee and Mah, 2017). It tried to penetrate into the global market since the late 1970s and automobile exports increased rapidly. In the midst of the Korean economic crisis in late 1990s, Hyundai acquired another Korean car manufacturer, Kia. Together with Kia, Hyundai successfully sold 8.1 million cars in 2015, which helped it become one of the world's top five car manufacturers (Hyun and Kim, 2016: 114).

In conclusion, Romania and Korea were able to gain national economic success through the development of their automobile industries led by Dacia and Hyundai, respectively. Furthermore, out of the two, Hyundai was able to gain a greater level of success with the help of technology licensing. It was able to penetrate many more markets around the globe and allowed the nation to become more self-reliant, which led to greater long-term economic benefits. Lastly, it can be concluded that, although currently underdeveloped or developing countries can utilize some of the efforts that were made by Romania and Korea, one approach may not fit for any country in the sense that the conditions of the concerned country may differ in terms of human capital, particular R\&D capabilities, and domestic market size, for instance.

\section{References}

Ahrens, A., \& Zweynert, J. (2012). Conditionality or Specificity? Bulgaria and Romania's Economic Transition Performance in Comparative Perspective. Post-Communist Economies, 24(2), 291-307.

Amsden, A. H. (1992). Asia's Next Giant: South Korea and Late Industrialization. Oxford: Oxford University Press.

Axenciuc, V., \& Georgescu, G. (2017). Gross Domestic Product - National Income of Romania 1862 - 2010. Secular statistical series and methodological foundations. MPRA Paper No. 86141. Retrieved January 12, 2019, from https://mpra.ub.uni-muenchen.de/84614/1/MPRA_paper_84614.pdf

Bernovici, A. (2015, May 7). Automobile Dacia, Still the Most Profitable Company in Romania - Turnover of EUR 4.24 Billion in 2014. The Romania Journal. Retrieved August 17, 2018, from https://www.romaniajournal.ro/automobile-dacia-still-the-most-profitable-company-in-romania-turnover-of-eur -4-24-bn-in-2014

Egresi, I. (2007). Foreign Direct Investment in a Recent Entrant to the EU: The Case of the Automotive Industry in Romania. Eurasian Geography and Economics, 48(6), 748-764.

Funaru, M., \& Funaru, G. (2011). Strategies of Dacia Renault on International Markets. Economic Sciences, 4(53), 31-36.

Graham, E. M. (2003). Reforming Korea's Industrial Conglomerates. Washington, D.C., WA: Institute for International Economics.

Groupe Renault. (2013a). The Dacia Saga \#1: 1965-1999, A Romanian Brand (January 4, 2013). Retrieved January 2, 2019, from https://group.renault.com/en/news/blog-renault/the-dacia-saga-1-1965-1999-a-romanian-brand

Groupe Renault. (2013b). The Dacia Saga \#2: 1999-2004, Birth of the Logan Project (January 15, 2013). Retrieved January $11, \quad 2019, \quad$ from https://group.renault.com/en/news/blog-renault/the-dacia-saga-2-birth-of-the-logan-project

Groupe Renault. (2018). Facts and Figures. Retrieved August 25, 2018, from https://group.renault.com/wp-content/uploads/2018/03/facts-figures-march-2018-edition.pdf

Haigh, R. (2018). The Most Valuable Automobile Brands of 2018. In Brand Finance. Retrieved January 7, 2019, from http://brandirectory.com/league_tables/table/auto-100-2018

Hyun, Y., \& Kim, J. (2016). The Multiple Crises and Innovation at Hyundai Motor in 2000s. Journal of Vocational Rehabilitation, 38(2), 105-123.

Kim, K. S. (1991). The Korean Miracle (1962-1980) Revisited: Myths and Realities in Strategy and Development. Kellogg Institute for International Studies working paper no. 166.

Koo, Y. (2013). Evolution of Industrial Policies and Economic Growth in Korea: Challenges, Crises and Responses. European Review of Industrial Economics and Policy, (7). 
Korea Automobile Manufacturers Association (KAMA). (2018). The Current State of Ten Largest Producers of Automobiles in 2017 (February 12, 2018) (in Korean).

Lansbury, R. D., Suh, C., \& Kwon, S. (2007). The Global Korean Motor Industry: The Hyundai Motor Company's Global Strategy. Abingdon, United Kingdom: Routledge.

Lee, J., \& Mah, J. (2017). The Role of the Government in the Development of the Automobile Industry in Korea. Progress in Development Studies, 17(3), 229-244.

Mah, J. (2007). Industrial Policy and Economic Development: Korea's Experience. Journal of Economic Issues, 41(1), 77-92.

Marica, I. (2018). Brand Finance: Dacia Tops Ranking of Most Valuable Romanian Brands (July 12, 2018). Retrieved July 12, 2018, from https://www.romania-insider.com/dacia-valuable-romanian-brands-2018

Martin, H. (2017). A Brief History of Dacia (November 19, 2017). Retrieved August 19, 2018, from https://www.osv.ltd.uk/brief-history-of-dacia

Myant, M., \& Drahokoupil, J. (2010). Transition Economies: Political Economy in Russia, Eastern Europe, and Central Asia: Political Economy in Russia, Eastern Europe, and Central Asia. Hoboken, NJ: John Wiley \& Sons.

Nedelcu, A. C. (2015). Romanian Automotive Industry - Analysis Made from The Intellectual Capital Perspective. Revista Economica, 67(5), 80-89.

Observatory of Economic Complexity (OEC). (2016). Retrieved August 29, 2018, from https://atlas.media.mit.edu/en/profile/country

Oh, Won Chul. (1996). Korea Type of Economic Construction (Vol. 4). Seoul: Kia Motors Research Institute (in Korean).

Romanian Automotive Manufacturers and Importers Association. (2019). Retrieved January 30, 2019, from http://www.apia.ro/publications/international-statistics/oica

Turi, A., Mocan, M., Ivascu, L., Goncalves, G., \& Maistor, S. (2015). From Fordism to Lean Management: Main Shifts in Automotive Industry Evolution within the Last Century. Presented at MakeLearn and TIIM Joint International Conference, May 27-29, 2015, Bari, Italy.

United Nations Conference on Trade and Development (UNCTAD). (2019). Data Center. Retrieved January 30, 2019, from http://unctadstat.unctad.org/wds

World Trade Organization (WTO). (2005). Trade Policy Review: Romania. Geneva: WTO.

Worrall, D., Donnelly, T., \& Morris, D. (2011). Industrial Restructuring: The Role of FDI, Joint Ventures, Acquisitions and Technology Transfer in Central Europe's Automotive Industry. Coventry University Business School working paper. 